where whips have proved ineffectual, if more drastic and more "courageous" methods of compelling the listing of intangible personalty will but be sanctioned.

Moreover, a comprehension of these sensational cases may lead here or there a grand jury of independence and intellectual vigor to refuse to return morally unwarranted indictments and to make a vigorous presentment setting forth the absolute and inevitable failure of the general property tax and urging the people to wipe it out of existence. This, of course, is what the Cook County grand jury should have done in view of the notorious and indisputable facts and genesis of our tax situation.

\title{
THE FINANCIAL CONDITION OF OHIO MUNICIPALITIES ${ }^{1}$
}

\author{
BY KARL F, GEISER \\ Oberlin, Ohio
}

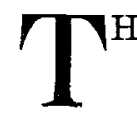

$\mathrm{HE}$ growth of cities and the reorganization of city governments throughout the United States, and the general extension of municipal activities, have forced the question of taxation to a position of first importance among all problems of government. In whatever form state constitutions, state laws and local conditions may force the problem upon the public, the common note running through all, everywhere, is a demand for greater local revenues. These revenues have increased during the last decade with the increase of population and the demand is still far from satisfied. The rising cost of municipal government in 146 cities of the United States, having a population of more than 30,000 , was estimated by the census bureau, and showed that while the population of these cities increased during a period of eleven years, ending with $1912,34.6$ per cent, the per capita cost of government increased 45.7 per cent, and the total cost increased 96.1 per cent. Moreover, this estimate showed that the average cost of government per capita was larger for cities having a population of over 500,000 than for those having a population from 30,000 to 50,000 , the cost in the former being $\$ 37.14$ per capita, while in the latter it was $\$ 22.17$.

These tendencies and conditions, with local variations, are also reflected in Ohio. The 82 municipalities in the state now contain more

1 This article by Professor Karl F. Geiser of Oberlin College, is a supplement to an article upon "Municipal Revenues in Ohio," in the April number, by Professor S. G. Lowrie, and should be read in connection with that article. The present article is based upon the "Report of the Committee for an Investigation of Finances of Municipalities" now published in "Bulletin of the Ohio Legislature Reference Department," Columbus, February 3, 1915.-EDrTor. 
than one-half of the population. In the ten largest cities the increase from 1900 to 1910 varies from 11.6 per cent in Cincinnati to 76.2 per cent in Youngstown, the average increase being 35.8 per cent. The total urban growth of the state during the last census decade was 33.4 per cent, while the rural population decreased 2.7 per cent. Since the increased cost of government is often explained by the character of the population, the following table for Ohio is of special significance:

Urban
Rural $\quad \begin{array}{lr}\text { Native white of native parentage, } & 51.0 \\ \text { Native white of foreign or mixed parentage, } & 28.0 \\ \text { Foreign born white, } & 17.9 \\ \text { Negro, } & 3.1 \\ \text { Native white of native parentage, } & 79.6 \\ \text { Native white of foreign or mixed parentage, } & 13.2 \\ \text { Foreign born white, } & 5.7 \\ \text { Negro, } & 1.4 \\ \text { large } & \text { Native white of native parentage, } \\ \text { Native white of foreign or mixed parentage, } & 63.6 \\ \text { Foreign born white, } & 21.5 \\ \text { Negro, } & 12.5 \\ \end{array}$

The relation between foreign and native population in rural and urban communities, shown in this table, will be more significant, if we call attention to the fact that the present general assembly of the state is dominated by rural representatives who control legislation, and who fail to appreciate the peculiar problems arising from a mixed municipal population. Statistics might also be cited to show that, while general laws might meet the conditions of rural communities, the character of the population in different cities varies greatly. Of the foreign born male population of Cincinnati, of voting age, only 7,983 are unnaturalized, while Cleveland has 48,047 unnaturalized male foreigners of voting age, and 59,127 persons of ten years of age and over, who are unable to speak English. Yet the percentage of illiterates in Cleveland is only 4.6 per cent, while illiteracy in Youngstown, with a population of 80,000 is estimated as high as 9 per cent. These facts suggest varying needs for different cities in the work of assimilation, sanitation, education, charities and social welfare. They also suggest that great care should be taken in the drafting of all laws affecting uniformly all the municipalities of the state.

Now, while the Ohio Constitutional amendments of 1912 did provide for just these varying conditions and needs in the home rule clause, the Smith "One Per Cent Law" 2 in effect destroyed the local freedom necessary to meet the problems, which the constitution forced upon the municipalities, by placing a ten mill limit upon the rate of taxation, with a maximum of fifteen mills by a vote of the people. This was the chief

2 Vol. iii, p. 254. 
cause of the present municipal embarrassment. Following the Smith law, which went into effect June 2, 1911, a series of enactments were put in force, which curtailed the revenue, and added to the cost of local government. A program of humanitarian and reform legislation was enacted, including laws relating to blind relief, mothers' pensions, workmen's compensation, special municipal courts, civil service commissions, an eight-hour day for public work, a revised method for the assessment of property for taxation and increasing election expenses through enlarging the field of the initiative and referendum. In a word, municipalities were forced by state legislation into wider activities upon a more limited budget.

The financial embarrassment has been further increased by a recent ruling of the attorney general based upon a decision of the supreme court holding the present budget commission law unconstitutional. The present law provides that the county budget commission, which also provides for the city budget, be composed of the county auditor, the mayor of the largest city and the city solicitor in counties where the city property exceeds that of the rural; and in counties where the rural property exceeds that of the city, the president of the school board is to take place of the city solicitor. The constitutional provision upon which the decision is based provides that the budget commissioners shall be elective county officers. In accordance with this ruling the legislature, which has just adjourned, passed an emergency act providing for a reorganization of the budget commission. It is now composed of the county auditor, the county treasurer, and the county prosecuting attorney. Thus another step has been taken to defeat the home rule principle; and since the legislature has adjourned without giving relief, this situation will continue for two years unless, in the meantime, an extra session is called, which is not at all probable.

\section{THE VINDICATION OF A. LEO. WEIL ${ }^{1}$}

$\mathbf{M}^{\mathrm{c}}$ UNICIPAL reformers and followers of civic movements were startled in January last by the press dispatches that $A$. Leo. Weil, the widely-known president of the Voters' League of Pittsburgh, and a member of the council of the National Municipal League, had been arrested in West Virginia "for an attempt to bribe the public service commissioners" of that state. Friends of Mr. Weil all over the United States, believing that the attack upon him must be in retaliation for some fight he was making against corruption, showered upon him letters and telegrams, expressing their confidence. A few days later Mr.

${ }^{1}$ This article has been prepared at the request of the editor of the NATIONAL MUNICIPAL REview by one who has had access to the testimony and court records and to the various articles published on the subject. C. R.W. 
Weil charged in court that his arrest was the result of a "frame-up" inspired by the governor of West Virginia to intimidate him and prevent him from proving that the governor dominated and controlled by illegal means the public service commission.

The public have anxiously awaited the story, which has now been brought out in court, completely vindicating Mr. Weil and corroborating his statement of the case. It has also once again shown him in the rôle of indomitable antagonism to corruption in public office, hitting hard regardless of the personal risks.

It seems that Mr. Weil, as general counsel for a natural gas company engaged in business in Pennsylvania, Ohio, and West Virginia, appeared at a rate hearing before the public service commission of West Virginia. With his wonted fearlessness he placed upon the record objections to the commission further proceeding with the hearing, because as he alleged the commissioners had been disqualified to sit as judges in the case, as they were dominated and controlled, and their findings in the case had been dictated in advance, by the chief magistrate, who had this power of coercion by reason of the fact that the commissioners were vacation appointments, not yet confirmed by the senate, and their names, or any of them, could be withdrawn at any time without explanation.

Having failed in efforts to drive Mr. Weil out of the case, and enraged at his exposure, Governor Hatfield, of the Hatfield family of feud fame, had Mr. Weil arrested while he was en route by train to Parkersburg, to attend a session of the federal district court, to urge the appointment of a master to take testimony in an equity suit brought in that court, to establish the facts in relation to these charges. Mr. Weil was arrested at midnight a few miles from Parkersburg, and in the custody of three officers like a desperate criminal, in spite of protest and offers to give bail, and a writ of habeas corpus issued by the federal judge; he was rushed through to Charleston and placed under excessive bail to appear a few days later for hearing before a justice of the peace. The night of the arrest, long before Mr. Weil reached Charleston, the news was given out to the press, that "A. Leo. Weil has been arrested for attempting to bribe the public service commissioners of West Virginia." It was no doubt expected that this publication would put a quietus upon the further efforts of Mr. Weil in the equity case. While the charge was thus labeled "attempted bribery," and so published, no such charge was ever made, as will presently appear. For the moment, however, the publicity was what was desired, and a less aggressive or less courageous fighter would have been completely cowed, but not so with Mr. Weil. He gave bail, got back to Parkersburg, and had the master appointed, the court having held over the case until Mr. Weil could return. On the application of Mr. Weil, and his statement in open court of what he proposed to prove, the master was given full power to inquire into the charges of coercion and domina- 
tion of the commissioners by the governor, and a hearing fixed for an early date.

On the day before the date fixed for the hearing before the justice of the peace, on the charge against Mr. Weil, a special grand jury was empaneled, so as to secure an indictment, and thus prevent the facts from being brought out at the hearing. When the indictments were found, however, notwithstanding the publicity given to the charges of attempted bribery, the public was amazed to learn that no charge of bribery at all was involved, but, instead, it was only claimed (and even this Mr. Weil has proven was untrue), that through several intermediaries a promise to two of the public service commissioners was made that if these commissioners were called as witnesses in the cases then pending in the United States courts, and, as such witnesses, told the truth about the governor's interference, and, because they told the truth, they were dismissed from office by the governor, and thus lost their positions and their salaries, in that event the company which Mr. Weil represented would get them positions at the same salaries. It was not even contended that these commissioners were asked to tell anything but the truth. There was not even a contention that these commissioners, as witnesses, were asked to do or tell anything more than the law required them to do or tell.

Under an extraordinary rule of the Charleston criminal court during the time a defendant is being tried upon a serious charge, he is locked up in jail, regardless of the amount of bail he could give, or of any other consideration. This was one of the prospects held over the head of $\mathrm{Mr}$. Weil, who accordingly applied to the state court having power of review of the criminal court, for a writ of prohibition, to prohibit the criminal court from proceeding with the trial under the indictment, upon the grounds that the indictments charged no crime, even if the allegations therein made were true; and that, in any event, the alleged attempt to interfere with a witness in the United States courts was triable exclusively in the United States courts, the state courts having no jurisdiction.

Meanwhile, the hearing was proceeded with before the master in the equity suit, and evidence was introduced from the mouths of some of the most prominent officials, lawyers and citizens of West Virginia, telling of statement after statement by the commissioners themselves, declaring in the most positive and emphatic terms that the governor absolutely controlled the commission, had directed the proceedings against the gas company, and had dictated what the decision should be even before the hearing was started, and that the commission was wholly dominated by the governor and obeyed his orders. Among other witnesses was an ex-governor, the chief clerk in the auditor's office, the reading clerk in the house of representatives, and numbers of prominent lawyers in the state, as well as other witnesses of the highest standing. There was also introduced a letter from one of the commissioners to the other commission- 
ers; a letter from the governor to the commission; an executive order to the commission directing procedure; and other documentary evidence. The proof of coercion and control of the commission by the governor was overwhelming.

On the hearing of the application for the writ of prohibition, the court awarded the writ, thus prohibiting and enjoining the criminal court from further proceeding, the judge saying:

I hold that the indictment does not charge that the defendant attempted to produce false testimony, or bribe a witness to swear falsely. I therefore think that the indictment is not good.

On the third question as to whether this defendant has committed an offence against the state law by attempting, as charged in the indictment, to procure evidence in the case pending in the federal court, I hold that the federal court has jurisdiction over that matter entirely, and that the intermediate court of this county has not. I therefore sustain the writ.

I do not find it a violation of the law for a man to offer a reward for the securing of the honest truth in any case in a court of justice, whether a man be litigant or lawyer. The truth can really hurt or wrong nobody.

From this decision the state has taken an appeal to the West Virginia supreme court of appeals, and that appeal will he heard some time this fall. Meantime the testimony before the master is proceeding. Mr. Weil has been upon the stand and has produced a number of witnesses, as well as documentary evidence, which would seem to show that the criminal proceedings against him were inspired by the governor to intimidate him and prevent him from making proof of the charge of coercion and domination of the commission by the governor. This evidence also shows that Mr. Weil did not authorize any one to make any promise of any kind to any of the commissioners, even a promise of reward for telling the truth; that while he had employed for his company a detective to rig up a dictaphone so as to get statements of two of the commissioners about the governor's coercion, this same detective, while apparently acting for Mr. Weil's clients, was in the pay of the governor, and it was the detective who authorized these offers to the commissioners, and not Mr. Weil, and turned over to the governor the evidence he was apparently getting for Mr. Weil's clients even Mr. Weil's letters to the detective agency. The man who made the offers to the commissioners testified that he had obtained his authority from the detective alone; that Mr. Weil had never given him any authority to make any promise whatever, but, on the contrary, when asked for such authority in the presence of three prominent lawyers, flatly refused, and stated that he would tolerate nothing of the kind. Mr. Weil testified to the same effect, denied that he had given any such authority to the detective, and was corroborated in this by his stenographer, who was present and took down in shorthand the instructions to the detective. The hearing has not been completed before the master, and Mr. Weil has stated in 
court that he has other witnesses yet to be examined, some of whom will give even more sensational testimony. of the governor's interference with the commission, and of his use of their decisions for his own political purposes.

The bar of West Virginia regard the indictment as a desperate experiment in criminal law, with no precedent for such a prosecution. It is certain that if the authorities had not been stimulated to such pernicious activity by the charges of wrong-doing that had been made by $\mathrm{Mr}$. Weil against the governor, no such desperate move to invoke the whole power of the criminal procedure of the state, along new and untried roads, would have been attempted.

The arrest of Mr. Weil at midnight, just within a few miles of Parkersburg, where he was to remain for some time; the hurrying of him under arrest to Charleston in charge of three officers; the demanding of excessive bail; the proceedings to avoid the hearing; the insidiousness of the charge sent out through the press the night of the arrest, that Mr. Weil had been "arrested for an attempt to bribe the public service commissioners," when this was not the charge; a letter from the governor to the presiding judge at Parkersburg who had under advisement the appointment of the master, which was published; interviews from time to time given out by the governor, and speeches made even since the decision on the writ of prohibition, in which the governor, notwithstanding the decision of the courts of his own state, reiterates the charge of bribery; all tend to sustain the charge of Mr. Weil that the governor is back of the whole proceeding, and that it was initiated to intimidate him and drive him from his pursuit of the governor in the equity case.

It is sad to contemplate how easily the telegraphic service of the newspapers of this country can be prostituted, while the service is innocent of wrong, for the purpose of destroying a man's reputation and good character. In this instance, again and again, both in the original news item and in the report of subsequent proceedings, the news agencies have headed the report with the statement: "A. Leo. Weil, who was arrested for an attempt to bribe the public service commissioners of West Virginia," while in fact there was no such charge made, and the publication of the real charge would have shown, even if true, that there was no moral turpitude charged in the complaint, much less any criminality. A man not so. well known as Mr. Weil, nor whose reputation was so well established, might have been ruined in the good opinion of the world by thesepublications. It is humiliating to any man, especially to a man like $\mathrm{Mr}$. Weil, who has made a reputation throughout this country as an implacable enemy of all sorts of graft, to have continued these false impressions. of the nature of the charges that were made against him-false impressions created by these misleading statements of the press, however innocently made or continued. There should be some way for the Associated Press and like agencies to correct the doing of such grievous wrong. 